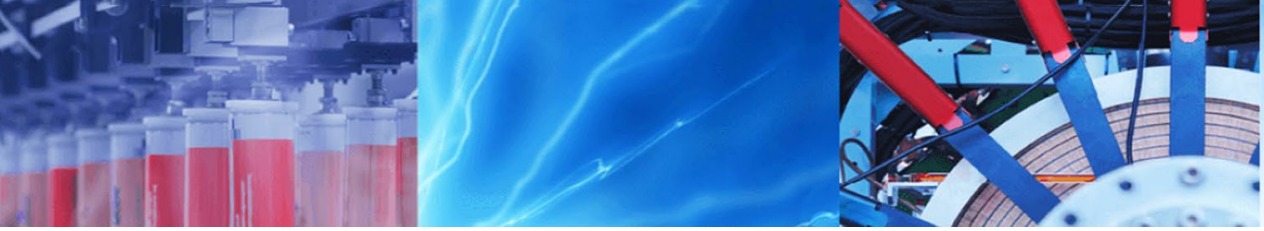

Research Article

\title{
Species and potential sources of phosphorus in groundwater in and around Mataram City, Lombok Island, Indonesia
}

\author{
Seiichiro loka ${ }^{1} \cdot$ Shin-ichi Onodera ${ }^{2} \cdot$ Mitsuyo Saito $^{3} \cdot$ Anna Rusydi $^{2,4} \cdot$ Hendra Bakti $^{4} \cdot$ Sachi A. Wakasa ${ }^{1}$
}

Received: 29 August 2020 / Accepted: 17 December 2020 / Published online: 7 January 2021

(C) The Author(s) $2020 \quad$ OPEN

\begin{abstract}
Geochemical evaluation of the species and potential sources of $\mathrm{P}$ in groundwater in and around Mataram City, Lombok Island, Indonesia can aid in the initial research on evaluating the fate of $\mathrm{P}$ when detailed geological information is unavailable. The results of ion chromatography and inductively coupled plasma-optical emission spectroscopy show that the concentrations of $\mathrm{PO}_{4}{ }^{3-}$ and total dissolved $\mathrm{P}$ (TDP) in groundwater range from approximately 0.1 to $8.5 \mathrm{mg} \mathrm{I}^{-1}$ and from 0.04 to $2.95 \mathrm{mg} \mathrm{l}^{-1}$, respectively. Dissolved inorganic $P$ accounted for $86 \%$, on average, of the TDP concentration, and $\mathrm{PO}_{4}{ }^{3-}$ represented the predominant $\mathrm{P}$ species in this groundwater. The potential sources for most of this dissolved $\mathrm{PO}_{4}{ }^{3-}$, according to indices developed based on the PHREEQC software and groundwater quality data, could be the dissolution of hydroxyapatite and/or vivianite minerals. However, the potential sources of dissolved $\mathrm{PO}_{4}{ }^{3-}$ in groundwater with a TDP concentration of $\geq 1 \mathrm{mg} \mathrm{l}^{-1}$ is likely to be the reduction of $\mathrm{Fe}(\mathrm{III})$-(hydro)oxides, the initial decomposition of organic matter, or the dissolution of carbonate-rich fluorapatite considering the $\mathrm{Fe}^{2+}$, dissolved organic carbon, $\mathrm{Ca}^{2+}$ and $\mathrm{F}^{-}$concentrations measured. In addition, as several groundwater samples had a TDP concentration of $\leq 1 \mathrm{mg} \mathrm{I}^{-1}$ and comparatively high concentration of $\mathrm{NO}_{3}{ }^{-}$, other potential sources of dissolved $\mathrm{PO}_{4}{ }^{3-}$ in this groundwater could be anthropogenic.
\end{abstract}

Keywords Phosphorus · Groundwater · Indonesia · Geochemical analysis

\section{Introduction}

In recent years, extensive research has been conducted on submarine groundwater discharge in tropical developing regions such as Indonesia because such groundwater discharge can be an important contributor of nutrients to coastal marine ecosystems [1-3]. This is particularly important in Indonesia, which hosts one of the largest coastal ecosystems consisting predominantly of coral reefs [4]. Therefore, it is important to clarify the nutrient cycle of submarine groundwater discharge processes in the area where this occurs and understand the nutrient cycle of groundwater in coastal recharge areas in Indonesia.
The population and the levels of industrial and economic activities including tourism are increasing rapidly in Indonesia, and understanding the impacts these have on the natural environment can lead to increased awareness about groundwater quality. Many studies on groundwater pollution, especially from nitrogen and arsenic, have been conducted in Indonesian coastal cities such as Jakarta, Mataram, and Indramayu [5-12]. However, phosphorus cycling in groundwater ecosystems, which relates to nutrients present in groundwater in such cities, has not been extensively investigated.

Previous detailed research on the phosphorus cycle in groundwater has been conducted mainly on highly

$\triangle$ Seiichiro loka, ioka@hirosaki-u.ac.jp | ${ }^{1}$ Institute of Regional Innovation, Hirosaki University, Aomori, Japan. ${ }^{2}$ Graduate School of Integrated Arts and Sciences, Hiroshima University, Higashihiroshima, Japan. ${ }^{3}$ Graduate School of Environmental and Life Sciences, Okayama University, Okayama, Japan. ${ }^{4}$ Research Center for Geotechnology, Indonesian Institute of Sciences, Bandung, Indonesia. 
contaminated septic systems in shallow sand aquifers [13-15]. In the UK, although the phosphorus cycle of groundwater in sandstone, chalk, and limestone aquifers-among others-has been described, phosphorus is still less characterized than nitrogen in groundwater [16]. In the USA, the subsurface transport of orthophosphate in five agricultural watersheds composed of deposits of sand and clayey silt, alluvium, sand and gravel, glacial debris, and quartz sand and gravel has been considered in the studies of stream water eutrophication $[17,18]$. In addition, Lewandoski et al. [19] extensively reviewed nutrient transport from groundwater to lake water. Given the adverse impacts of high nutrient concentrations in ecosystems, there is urgent need for detailed research to quantify the different sources of nutrients in groundwater and the likelihood of these being transported, transformed, and stored along flow paths [19]. More recently, there have been an increasing number of studies on the phosphorus cycle as it relates to arsenic contamination in groundwater in South and Southeast Asian floodplains and delta aquifers $[20,21]$. However, the complete analysis of the phosphorus cycle in aquifers in volcanic deposits on a volcanic island has yet to be conducted.

Therefore, herein, the area around Mataram City, which is located on the coast of a volcanic island, is used as a study site. The main objectives of this study were to 1) study the species and distribution of phosphorus in the local groundwater and 2) evaluate potential sources of phosphorus and its species using groundwater quality data. Future research will focus on submarine groundwater in this area.

\section{Study site}

The island of Lombok is a part of the Lesser Sunda Islands chain, with the Lombok Strait dividing Bali to the west and Sumbawa to the east. It experiences consistent sunlight for several hours and a warm temperature throughout the year-a minimum of $24^{\circ} \mathrm{C}$ and a maximum of $34^{\circ} \mathrm{C}$ during hot months and $20^{\circ} \mathrm{C}-31^{\circ} \mathrm{C}$ during cooler months. There is a dry season that runs from April to September and a rainy season that stretches from October to March [22].

One of the most striking features of the Lombok Island region is that most of its cities and densely populated settlements are located in valleys or sedimentary basins or on hills. It has a total area of $4,725 \mathrm{~km}^{2}$ and is a part of the West Nusa Tenggara Province of Indonesia. The provincial capital and largest city is Mataram, which is located on the western part of the island. The population of Mataram was 441,064 in 2015 [23].

The Lombok Island region experiences a very high level of seismic activity; the last known eruption was in
September 2016 and the most recent earthquake with a magnitude of 6.9 occurred in September 2018. This is due to its position in the Indian Ocean, which places it adjacent to the zone of collision between the Eurasian and Indo-Australian plates [24]. Lombok Island is composed of relatively young Tertiary to Quaternary sediment. The lithology of Lombok Island is dominated by volcanic rocks such as volcanic breccia, various igneous rocks, and sandstone. The eastern part of Lombok Island is formed of breccia, igneous rock, and tuff, among others, from the Tertiary sediment; the western part of the island consists of alluvial or loose rock such as sand, gravel and mud; and the northern part of the island consists of Quaternary volcanic rock [24]. In Antareja, Mataram City, the first layer is composed of smoothly alternating of clay, sand, gravel, coarse grains of pumice, mud, and black sand, with an average thickness of $13 \mathrm{~m}$, extending up to a depth of $28 \mathrm{~m}$ from the ground surface. The second layer consists of fine sand and black mud. The third layer is silt and fine sand saturated with water and occurs at an average depth of $39 \mathrm{~m}$ from the ground surface. The third layer, which began at a depth of $47 \mathrm{~m}$ from the ground surface, is interpreted as the bedrock consisting of sandstone and mudstone [25]. The rock that made up the layers of the bed of the volcanic deposits included clay, gravel, pumice sand, sand, rough pumice granules, silt, and fine black sand [25].

\section{Hydrochemical sampling and analyses}

Groundwater samples were obtained from 19 wells in and around Mataram City and 1 natural spring (Fig. 1). The sampling points were located in an alluvial formation, dating from the Holocene period [26], and consists of pebbles, granule, sand, clay, peat, and fragments of coral (Fig. 2). It is a lowland surrounded by volcanoes (part of the Kalibabak and Pengulung formations). Standing water equivalent to at least one well volume was drawn from the wells before the groundwater samples were collected. The sampling campaign was conducted from September 4-7, 2017, i.e., during the dry season. Field measurements of the $\mathrm{pH}$ of the water at its surface were carried out using a $\mathrm{pH}$ meter (WM-32EP, DKK-TOA Co.).

Water samples were typically collected over a period of 1-2 h. First, unfiltered splits were taken for the field measurements of $\mathrm{pH}$ and the laboratory measurements of alkalinity; samples for the latter were collected in $100 \mathrm{~mL}$ polyethylene bottles. Filtered splits (filter: polytetrafluoroethylene; DISMIC-25 ${ }_{\mathrm{HP}}$; pore size: $0.2 \mu \mathrm{m}$ ) were taken for the laboratory measurements of dissolved organic carbon (DOC) and cation and anion concentrations. Subsamples of the filtered water sample were transferred to $100 \mathrm{~mL}$ polyethylene bottles and acidified to $\mathrm{pH}<2$ using ultrapure 


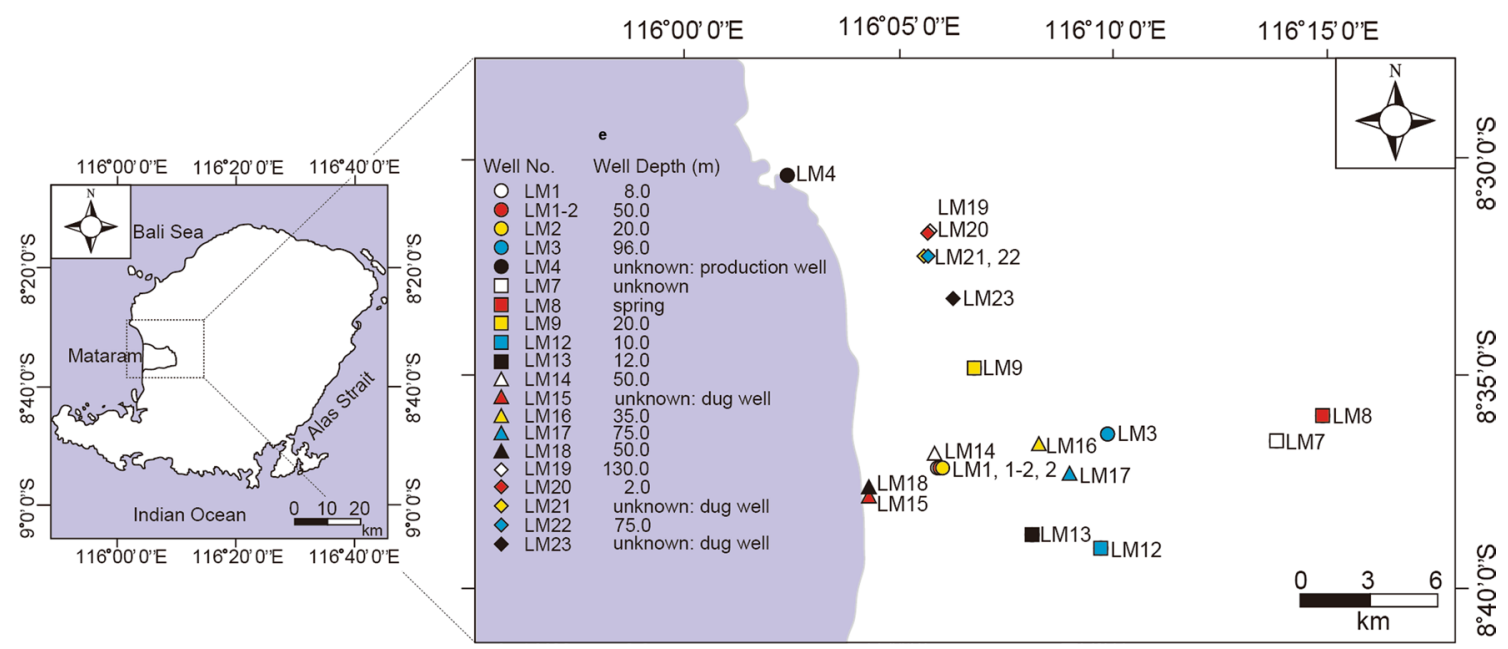

Fig. 1 Study area and sampling locations in and around Mataram

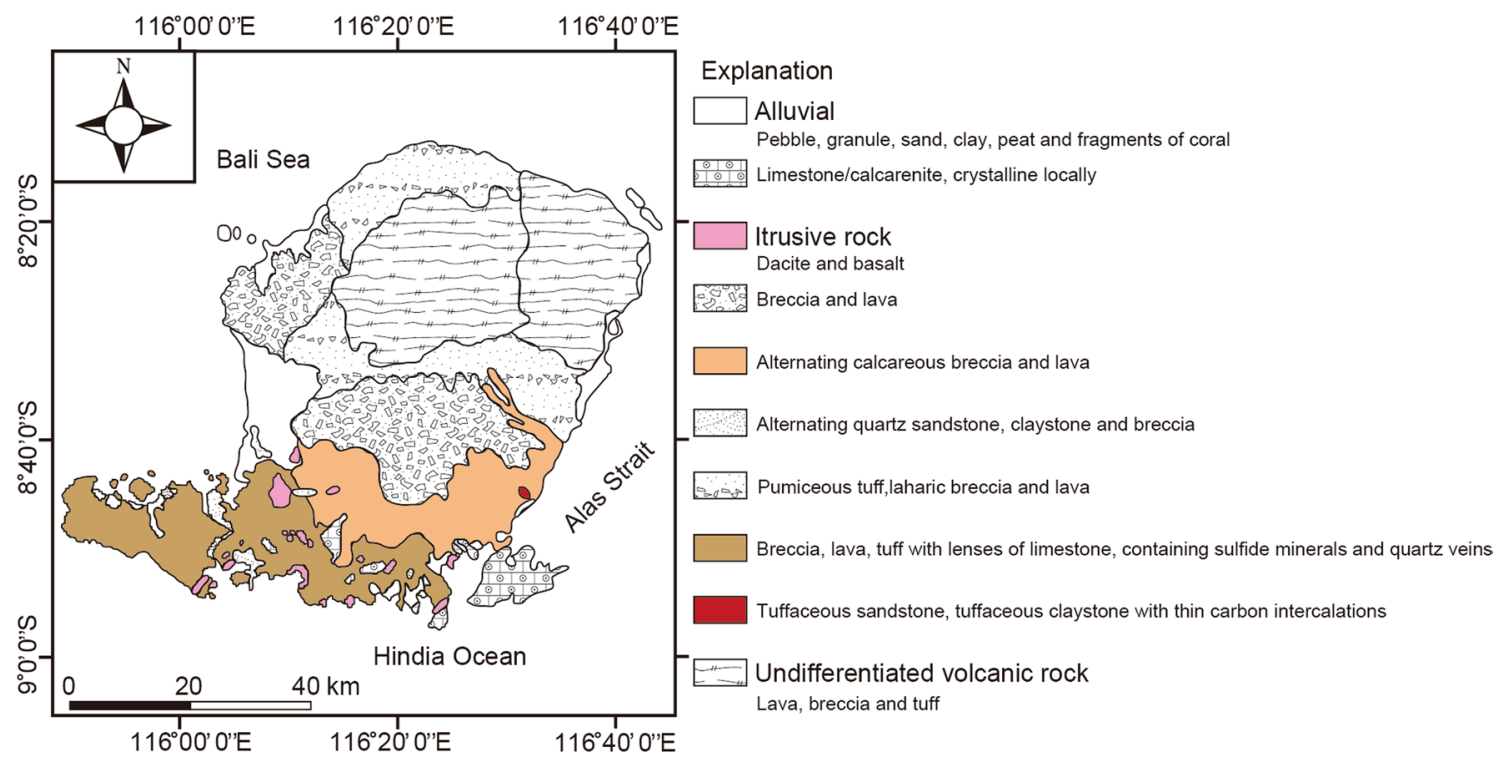

Fig. 2 Geology of Lombok Island (adapted from [26])

nitric acid before the concentrations of $\mathrm{Fe}, \mathrm{Mn}, \mathrm{Sr}, \mathrm{Ba}, \mathrm{B}$, $\mathrm{Cu}, \mathrm{Zn}, \mathrm{Si}$, and $\mathrm{P}$ were measured. Unacidified splits needed for cation $\left(\mathrm{Na}^{+}, \mathrm{NH}_{4}^{+}, \mathrm{K}^{+}, \mathrm{Mg}^{2+}\right.$, and $\left.\mathrm{Ca}^{2+}\right)$ and anion $\left(\mathrm{F}^{-}, \mathrm{Cl}^{-}\right.$, $\mathrm{Br}^{-}, \mathrm{NO}_{3}{ }^{-}, \mathrm{PO}_{4}{ }^{3-}$ and $\mathrm{SO}_{4}{ }^{2-}$ ) analyses were kept in $100-\mathrm{mL}$ polyethylene bottles, while those for $\mathrm{DOC}$ estimation were kept in $50 \mathrm{~mL}$ glass vials.

The elemental analyses were performed at the geothermal engineering laboratory at Hirosaki University, where the concentrations of $\mathrm{Fe}, \mathrm{Mn}, \mathrm{Sr}, \mathrm{Ba}, \mathrm{B}, \mathrm{Cu}, \mathrm{Zn}, \mathrm{Si}$, and P were determined using inductively coupled plasma-optical emission spectroscopy (Optima 7000DV, PerkinElmer Co. Ltd.). The concentrations of $\mathrm{Na}^{+}, \mathrm{NH}_{4}{ }^{+}, \mathrm{K}^{+}, \mathrm{Mg}^{2+}$, and $\mathrm{Ca}^{2+}$ were determined via ion chromatography with conductivity detection (ICS-1100, Thermo Fisher Scientific
Inc.). The concentrations of $\mathrm{F}^{-}, \mathrm{Cl}^{-}, \mathrm{Br}^{-}, \mathrm{NO}_{3}{ }^{-}, \mathrm{PO}_{4}{ }^{3-}$, and $\mathrm{SO}_{4}{ }^{2-}$ were determined via ion chromatography with conductivity detection (ICS-2100, Thermo Fisher Scientific Inc.). The DOC concentration was measured using a total organic carbon analyzer (TOC-V $\mathrm{VPH}_{\mathrm{CH}}$ Shimadzu Co.). Alkalinity measurements were carried out in the field via titration, and the values were expressed in terms of the concentration of $\mathrm{HCO}_{3}{ }^{-}$(milligrams per liter of water). In terms of the error in the charge balance between the cations and anions, 16 samples were within $\pm 3 \%$, 2 were within $+4 \%$, and another 2 samples were within $+9 \%$.

The saturation indices ( $\mathrm{SI}=\log$ (ion activity product/solubility product)) of the groundwater samples were calculated using the thermodynamic database 
(phreeqc.dat) for a mineral phase that might serve as a sink or source for $\mathrm{PO}_{4}{ }^{3-}$, as provided with the aqueous speciation software PHREEQC ver.3 [27]. An annual average air temperature of $27^{\circ} \mathrm{C}$ was used as the temperature of analysis because the actual temperature of the groundwater in situ was unknown.

\section{Results and discussion}

\subsection{Phosphorus species and distribution}

The dissolved phosphorus species in 19 samples of groundwater and 1 sample of spring water taken in and around Mataram City were analyzed and the concentrations of total dissolved phosphorus (TDP; or total filterable phosphorus [28]) and $\mathrm{PO}_{4}{ }^{3-}$ were determined. The concentrations of TDP and dissolved $\mathrm{PO}_{4}-\mathrm{P}$, as measured using inductively coupled plasma-optical emission spectroscopy and ion chromatography, ranged from $0.04 \mathrm{mg} \mathrm{l}^{-1}$ to $2.95 \mathrm{mg} \mathrm{l}^{-1}$ and from 0.028 to $2.74 \mathrm{mg} \mathrm{l}^{-1}$, respectively (Table 1 ). The concentration of dissolved $\mathrm{PO}_{4}-\mathrm{P}$ of groundwater from parts of Lombok Island that were outside the study area, measured using standard photochemical methods, ranged from 0.018 to $0.384 \mathrm{mg} \mathrm{I}^{-1}$ (i.e., ranged from 0.58 to $12.4 \mu \mathrm{mol} \mathrm{I}^{-1}$ as $\mathrm{PO}_{4}$ ) according to Oehler et al. [3]. The ratio of dissolved $\mathrm{PO}_{4}-\mathrm{P}$ that was related to TDP ranged from 67 to $96 \%$; exceptions were values of $14 \%, 35 \%$, and $172 \%$, respectively, in wells LM9, LM15, and LM4 (Table 1). The reason for the high value from well LM4 is unknown; however, the very low values (14\% and $35 \%$ ) from wells LM9 and LM 15 could possibly be due to the fact that two groundwater samples with a high $\mathrm{Fe}^{2+}$ concentration (1.70 and $2.71 \mathrm{mg} \mathrm{l}^{-1}$ ) were precipitated before the ion chromatography analysis, while $\mathrm{PO}_{4}{ }^{3-}$ in the groundwater samples was co-precipitated with Fe(III)-(hydr)oxides [21, 29]. Dissolved inorganic $P$ accounted for $86 \%$, on average, of the TDP concentrations, while $\mathrm{PO}_{4}{ }^{3-}$ represented the predominant ion species in this groundwater. The latter result is similar to that obtained in the analyses of groundwater in Asian floodplain and delta aquifers [21]. Figure 3 shows the relationship between TDP concentration and well depth; if the latter was unknown, it is described in the caption of Fig. 3. It was found that the groundwater from wells LM1-2, LM14, and LM18 sampled from wells with a depth of $50 \mathrm{~m}$ contained more $P$ compared with samples taken from wells of other depths (Fig. 3). The TDP concentration of these samples was also relatively high, compared to the others.

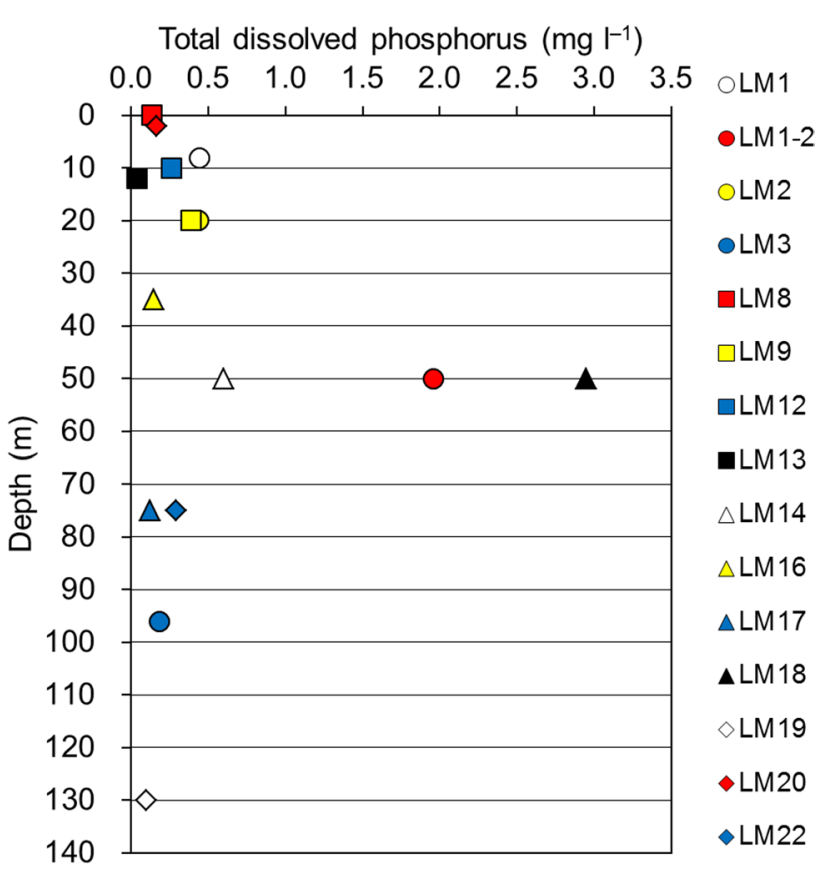

Fig. 3 Depth distribution of total dissolved phosphorus $\left(\mathrm{mg} \mathrm{l}^{-1}\right)$. The total phosphorus concentrations in the observation wells of unknown depth, LM4, LM7, LM15, LM21, and LM23 were $0.12,0.10$, $1.31,0.88$, and $0.30 \mathrm{mg} \mathrm{I}^{-1}$, respectively

\subsection{Potential sources of dissolved $\mathrm{PO}_{4}{ }^{3-}$}

One possible source of dissolved $\mathrm{PO}_{4}{ }^{3-}$ is the dissolution of minerals (e.g., apatite) that may contain $\mathrm{P}$ in some phases $[21,30,31]$. Volcanic rocks and deposits contain P [32, 33], as does lava on Lombok Island; for the latter, the levels of $P$ detected were reported as percentages of $\mathrm{P}_{2} \mathrm{O}_{5}$ ranging from 0.15 to 0.47 [34] and 0.19 to 0.27 [35]. The presence of apatite was also reported [35]. In addition, the microbial degradation of organic carbon (sedimentary and dissolved) and the concomitant reductive dissolution of $\mathrm{Fe}(\mathrm{III})$-(hydro)oxides represent another potential source of $\mathrm{P}$ that could have released $\mathrm{PO}_{4}{ }^{3-}$ into groundwater [21]. Other potential sources include leachate from arable land and leaking septic tanks or sewer pipes $[13-15,17,18,36]$.

Taking the first potential source into consideration, the contribution of the dissolution of hydroxyapatite and vivianite was evaluated on the basis of the calculated SI (Figs. 4 and 5). Only groundwater sampled from well LM15 appeared to be over-saturated with hydroxyapatite and vivianite. The groundwater sampled from wells LM1-2, LM14, and LM 18 were over-saturated with hydroxyapatite only (Fig. 4). In addition, the groundwater sampled from wells LM17 and LM22 was nearly saturated with hydroxyapatite (Fig. 4), while that sampled from well LM18 was nearly saturated with vivianite (Fig. 5). Thus, the dissolved $\mathrm{PO}_{4}{ }^{3-}$ in groundwater from 


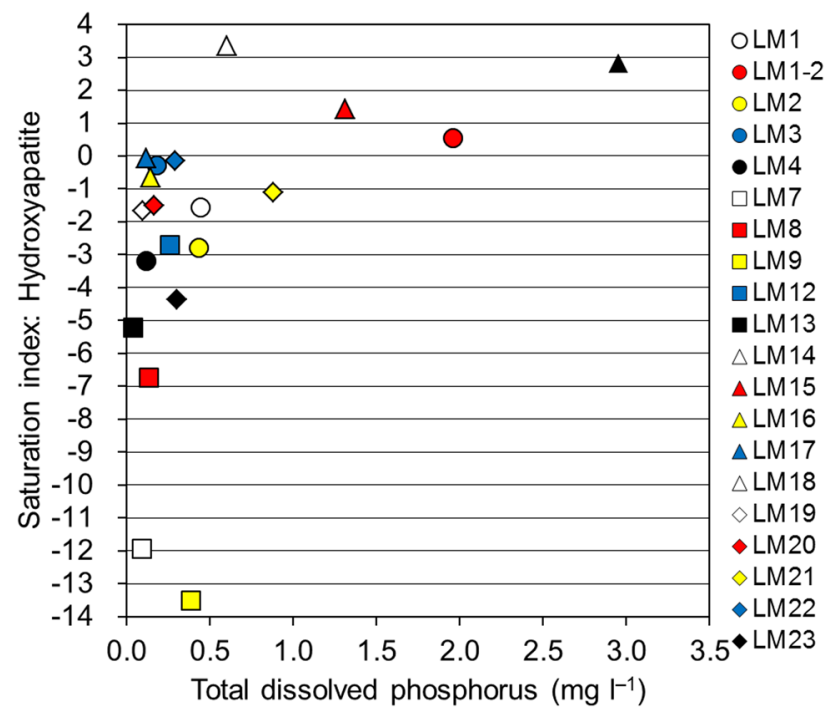

Fig. 4 Saturation index for a potential phosphate-bearing phase of hydroxyapatite, as calculated by PHREEQC. For the PHREEQC analysis of the groundwater sampled from wells LM9 and LM15, the concentrations of total dissolved phosphorus, instead of $\mathrm{PO}_{4}{ }^{3-}$, were used as the input value for $P$

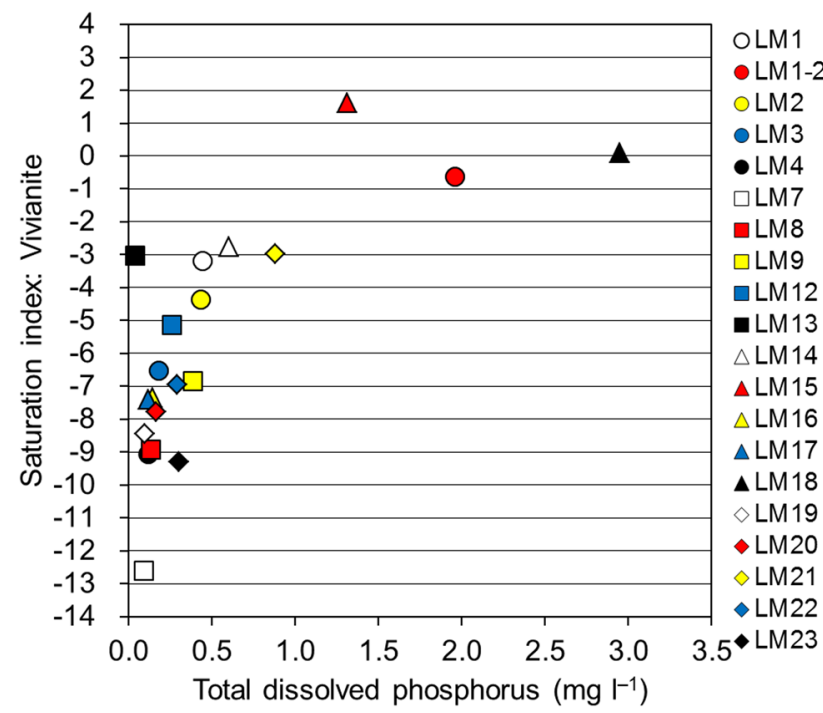

Fig. 5 Saturation index for a potential phosphate-bearing phase of vivianite, as calculated by PHREEQC. For the PHREEQC analysis of the groundwater sampled from wells LM9 and LM15, the concentrations of total dissolved phosphate, instead of $\mathrm{PO}_{4}{ }^{3}-$, were used as the input value for $P$. All Fe concentrations measured using inductively coupled plasma-optical emission spectroscopy were input to PHREEQC as $\mathrm{Fe}^{2+}$. When the Fe concentration measured using this method was less than the lower limit of quantification, the lower limit of quantification was entered in PHREEQC

all the samples could potentially be sourced through the dissolution of hydroxyapatite and/or vivianite. Notably, the presence of apatite in volcanic lava deposits from

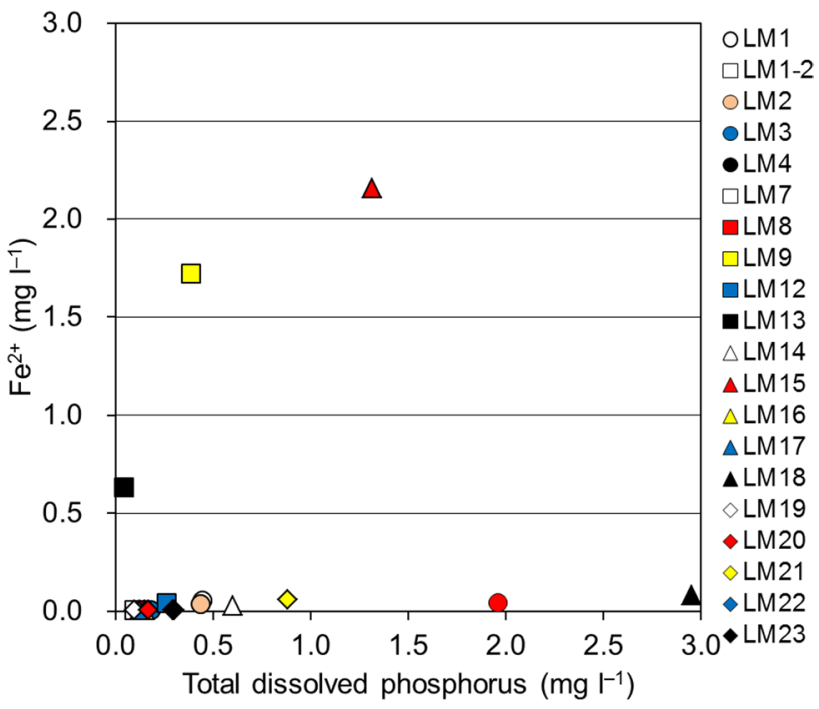

Fig. 6 Relationship between the concentrations of $\mathrm{Fe}^{2+}$ and total dissolved phosphorus. When the $\mathrm{Fe}^{2+}$ concentration was less than the lower limit of quantification, the latter was entered in PHREEQC

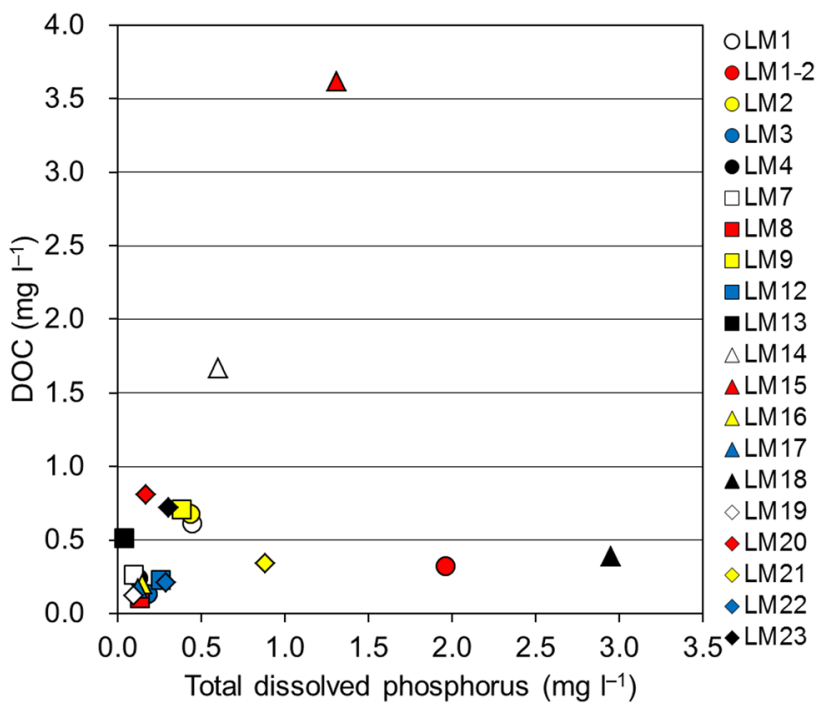

Fig. 7 Relationship between the concentrations of dissolved organic carbon and total dissolved phosphorus

Mount Rinjani has already been reported [35]. However, only well LM15 may have other sources.

The groundwater sampled from well LM15 contained $1.31 \mathrm{mg} \mathrm{l}^{-1}$ of TDP and high concentrations of $\mathrm{Fe}^{2+}, \mathrm{DOC}$, and $\mathrm{NH}_{4}^{+}$(Figs. 6, 7, and 8). Thus, the reduction of $\mathrm{Fe}$ (III)-(hydro)oxides or the initial decomposition of organic matter are considered potential key mechanisms underlying the enrichment of $\mathrm{PO}_{4}{ }^{3-}$ in groundwater from this well. Furthermore, one characteristic of the groundwater sampled from wells LM1-2 and LM18 is that 


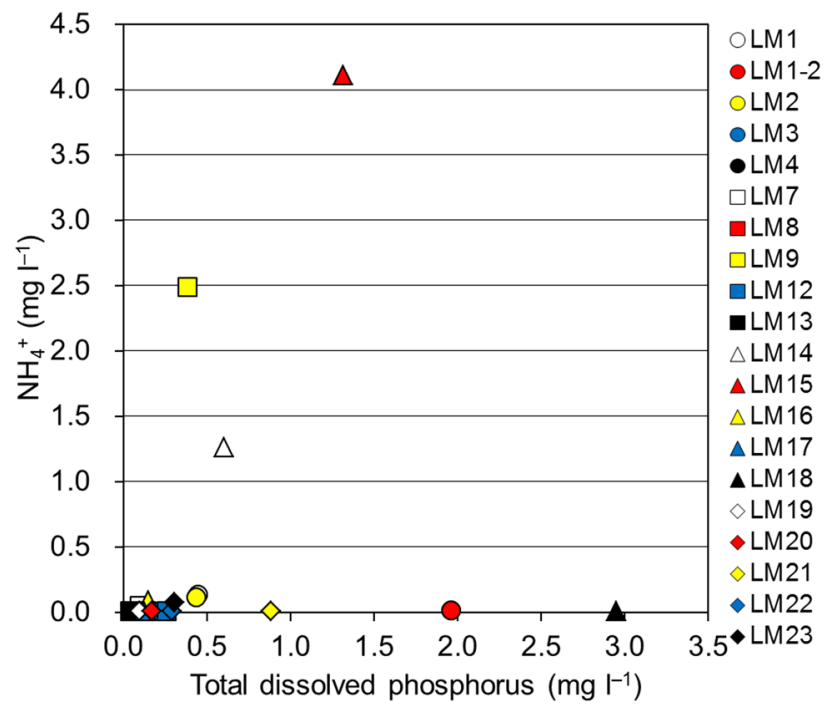

Fig. 8 Relationship between the concentrations of $\mathrm{NH}_{4}^{+}$and total dissolved phosphorus. When the $\mathrm{NH}_{4}{ }^{+}$concentration was less than the lower limit of quantification, the latter was entered in PHREEQC

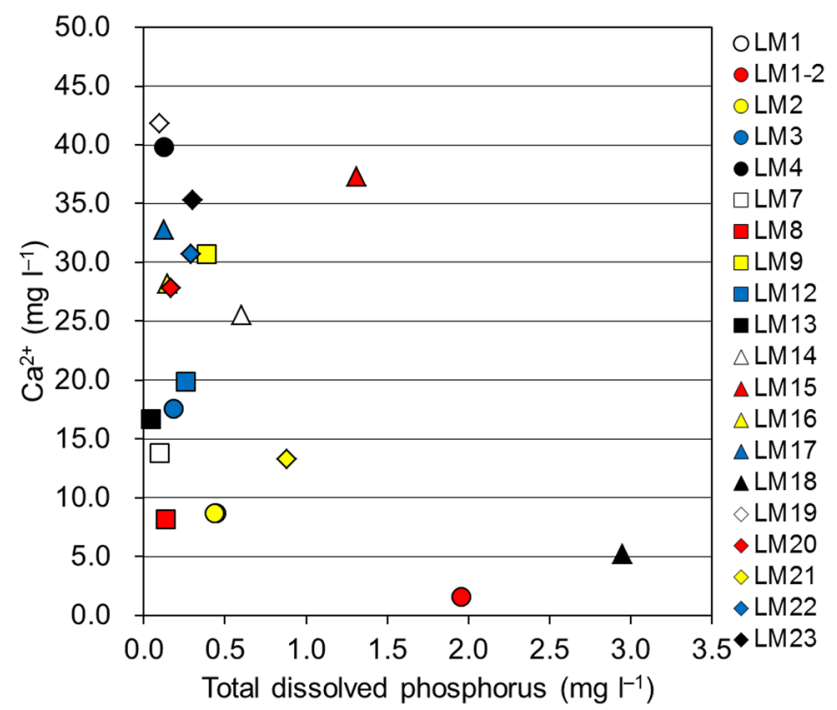

Fig. 9 Relationship between the concentrations of $\mathrm{Ca}^{2+}$ and total dissolved phosphorus

the $\mathrm{Ca}^{2+}$ concentrations are very low, at $1.57 \mathrm{mg} \mathrm{l}^{-1}$ and $5.8 \mathrm{mg} \mathrm{l}^{-1}$, respectively, while the concentrations of $\mathrm{F}^{-}$are high at $1.14 \mathrm{mg} \mathrm{l}^{-1}$ and $1.76 \mathrm{mg} \mathrm{I}^{-1}$, respectively (Figs. 9 and 10). In addition, the concentrations of DOC, $\mathrm{Fe}^{2+}$, $\mathrm{NO}_{3}{ }^{-}$, and $\mathrm{NH}_{4}{ }^{+}$in these samples were low (Figs. 6, 7, 8, and 11). These results indicate that the origin of dissolved $\mathrm{PO}_{4}{ }^{3-}$ in these wells is neither the microbial degradation of organic carbon nor the concomitant reductive dissolution of Fe(III)-(hydro)oxides. Furthermore, these results show that there is no anthropogenic influence here as these samples contain no $\mathrm{N}$ components. Thus, the dissolved

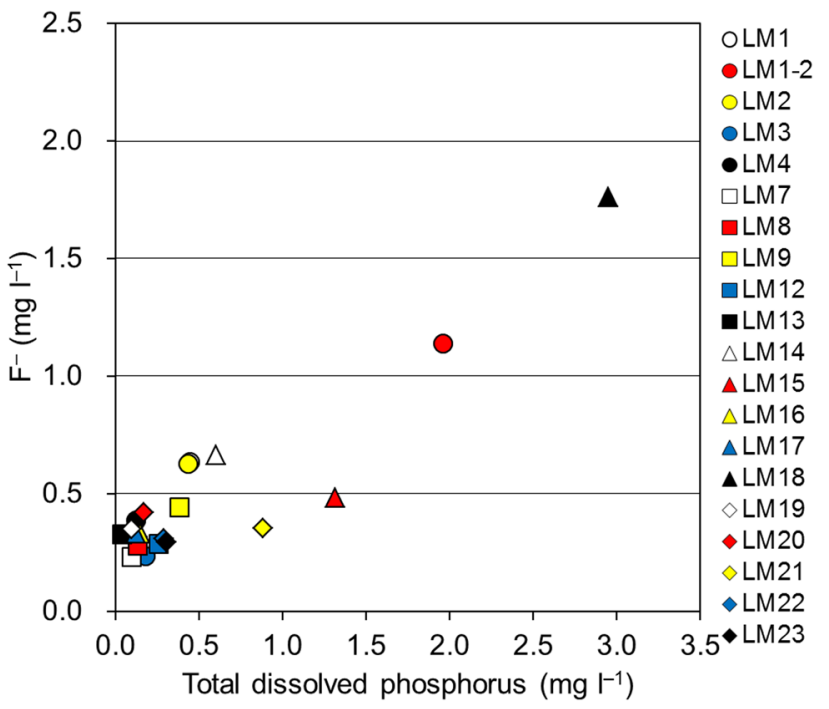

Fig. 10 Relationship between the concentrations of $\mathrm{F}^{-}$and total dissolved phosphorus

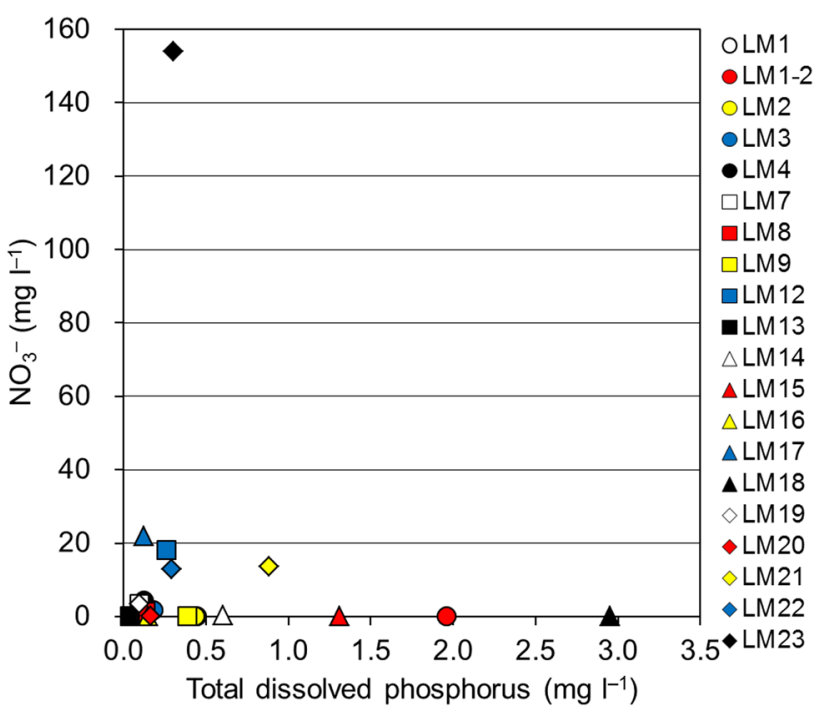

Fig. 11 Relationship between $\mathrm{NO}_{3}{ }^{-}$and concentrations of total dissolved phosphorus. When the $\mathrm{NO}_{3}{ }^{-}$concentration was less than the lower limit of quantification, the latter was entered in PHREEQC

$\mathrm{PO}_{4}{ }^{3-}$ in these samples may be considered to have a geological origin - the dissolution of carbonate-rich fluorapatite [31]. The low $\mathrm{Ca}^{2+}$ concentrations are most likely a result of several mechanisms, including (1) mostly cation exchange reactions and (2) to a lesser degree, the formation of the hydrated di-basic calcium phosphate surface and sorption [31].

Finally, the groundwater sampled from well LM14 had high DOC and $\mathrm{NH}_{4}{ }^{+}$concentrations (Figs. 7 and 8). The decomposition of organic matter is considered the potential source of dissolved $\mathrm{PO}_{4}{ }^{3-}$ in these groundwater 
Table 1 Groundwater quality data

\begin{tabular}{|c|c|c|c|c|c|c|c|c|c|c|c|c|c|}
\hline & \multirow[b]{2}{*}{$\mathrm{pH}$} & \multicolumn{12}{|l|}{$\mathrm{mg} \mathrm{l}^{-1}$} \\
\hline & & DOC & $\mathrm{F}^{-}$ & $\mathrm{Cl}^{-}$ & $\mathrm{Br}^{-}$ & $\mathrm{NO}_{3}^{-}$ & $\mathrm{SO}_{4}{ }^{2-}$ & $\mathrm{PO}_{4}{ }^{3-}$ & $\mathrm{HCO}_{3}^{-}$ & $\mathrm{Na}^{+}$ & $\mathrm{NH}_{4}^{+}$ & $\mathrm{K}^{+}$ & $\mathrm{Mg}^{2+}$ \\
\hline LM1 & 7.45 & 0.61 & 0.635 & 6.39 & 0.032 & $<0.01$ & 0.854 & 1.23 & 220 & 29.9 & 0.135 & 11.3 & 21.8 \\
\hline LM1-2 & 8.26 & 0.32 & 1.14 & 5.45 & 0.016 & $<0.01$ & 4.89 & 5.64 & 259 & 97.7 & 0.017 & 5.98 & 0.452 \\
\hline LM2 & 7.20 & 0.68 & 0.629 & 6.36 & 0.031 & 0.012 & 0.822 & 1.20 & 221 & 29.9 & 0.118 & 11.5 & 22.0 \\
\hline LM3 & 7.62 & 0.13 & 0.236 & 3.13 & 0.012 & 1.73 & 4.45 & 0.47 & 144 & 15.5 & $<0.01$ & 4.43 & 11.2 \\
\hline LM4 & 6.77 & 0.24 & 0.388 & 229 & 0.771 & 4.47 & 39.3 & 0.64 & 281 & 187 & $<0.01$ & 6.89 & 21.1 \\
\hline LM7 & 5.85 & 0.26 & 0.231 & 3.82 & 0.008 & 3.37 & 5.67 & 0.228 & 94.6 & 12.4 & 0.049 & 5.37 & 6.49 \\
\hline LM8 & 6.70 & 0.1 & 0.281 & 4.72 & 0.01 & 1.16 & 4.56 & 0.377 & 65.3 & 10.3 & 0.010 & 3.63 & 4.70 \\
\hline LM9 & 5.10 & 0.71 & 0.441 & 16.3 & 0.03 & 0.1 & 8.22 & 0.16 & 213 & 25.9 & 2.49 & 12.4 & 12.6 \\
\hline LM12 & 7.02 & 0.23 & 0.285 & 10.5 & 0.018 & 18.0 & 10.2 & 0.609 & 150 & 23.8 & $<0.01$ & 11.4 & 11.4 \\
\hline LM13 & 7.12 & 0.51 & 0.329 & 56.9 & 0.043 & $<0.01$ & 14.30 & 0.085 & 174 & 64.0 & $<0.01$ & 12.5 & 10.4 \\
\hline LM14 & 7.92 & 1.67 & 0.664 & 14.9 & 0.043 & 0.4 & 2.81 & 1.76 & 236 & 67.7 & 1.26 & 12.9 & 6.46 \\
\hline LM15 & 7.17 & 3.62 & 0.482 & 40.3 & 0.103 & 0.01 & 0.619 & 1.42 & 339 & 58.5 & 4.11 & 26.4 & 17.9 \\
\hline LM16 & 7.48 & 0.20 & 0.331 & 8.42 & 0.064 & 0.027 & 8.56 & 0.317 & 180 & 20.2 & 0.088 & 4.86 & 15.1 \\
\hline LM17 & 7.60 & 0.17 & 0.330 & 17.6 & 0.039 & 22.0 & 13.0 & 0.35 & 293 & 38.0 & $<0.01$ & 6.49 & 31.5 \\
\hline LM18 & 8.18 & 0.39 & 1.76 & 133 & 0.456 & $<0.01$ & 24.5 & 8.4 & 326 & 204 & $<0.01$ & 9.60 & 2.84 \\
\hline LM19 & 7.17 & 0.12 & 0.348 & 12.7 & 0.049 & 3.51 & 8.16 & 0.280 & 249 & 28.6 & $<0.01$ & 2.48 & 19.4 \\
\hline LM20 & 7.23 & 0.81 & 0.419 & 12.9 & 0.031 & $<0.01$ & 14.3 & 0.422 & 234 & 41.8 & $<0.01$ & 16.8 & 9.88 \\
\hline LM21 & 7.11 & 0.34 & 0.353 & 10.5 & 0.023 & 13.5 & 7.22 & 2.38 & 105 & 21.1 & $<0.01$ & 18.3 & 4.93 \\
\hline LM22 & 7.27 & 0.21 & 0.309 & 14.9 & 0.042 & 12.8 & 9.28 & 0.816 & 135 & 24.6 & $<0.01$ & 6.33 & 10.7 \\
\hline \multirow[t]{3}{*}{ LM23 } & 6.50 & 0.72 & 0.294 & 30.0 & 0.039 & 154 & 11.0 & 0.779 & 70.6 & 38.7 & 0.075 & 10.4 & 13.2 \\
\hline & & \multicolumn{12}{|l|}{$\mathrm{mgl}^{-1}$} \\
\hline & $\mathrm{pH}$ & $\overline{\mathrm{Ca}^{2+}}$ & $\mathrm{Fe}$ & $\mathrm{Mn}$ & $\mathrm{Sr}$ & $\mathrm{Ba}$ & B & $\mathrm{Cu}$ & $\mathrm{Zn}$ & $\mathrm{Si}$ & $\mathrm{TDP}^{* * *}$ & $\mathrm{PO}_{4}-\mathrm{P}^{*}$ & $\mathrm{PO}_{4}-\mathrm{PTDP}^{-1}$ \\
\hline LM1 & 7.45 & 8.69 & 0.054 & 0.220 & 0.097 & 0.020 & 0.081 & $<0.004$ & 0.021 & 36.9 & 0.44 & 0.401 & $90 \%$ \\
\hline LM1-2 & 8.26 & 1.57 & 0.042 & 0.006 & 0.023 & 0.016 & 0.101 & $<0.004$ & 0.051 & 22.2 & 1.96 & 1.839 & $94 \%$ \\
\hline LM2 & 7.20 & 8.71 & 0.036 & 0.147 & 0.098 & 0.018 & 0.081 & $<0.004$ & 0.007 & 32 & 0.44 & 0.391 & $90 \%$ \\
\hline LM3 & 7.62 & 17.6 & $<0.005$ & $<0.001$ & 0.093 & 0.004 & 0.036 & $<0.004$ & $<0.003$ & 38 & 0.18 & 0.153 & $84 \%$ \\
\hline LM4 & 6.77 & 39.8 & $<0.005$ & $<0.001$ & 0.384 & 0.002 & 0.069 & $<0.004$ & 0.096 & 42.5 & 0.12 & 0.209 & $172 \%$ \\
\hline LM7 & 5.85 & 13.8 & $<0.005$ & 0.001 & 0.102 & 0.004 & 0.039 & 0.004 & 0.016 & 31.4 & 0.10 & 0.074 & $78 \%$ \\
\hline LM8 & 6.70 & 8.16 & $<0.005$ & 0.001 & 0.052 & 0.002 & 0.097 & $<0.004$ & $<0.003$ & 27 & 0.13 & 0.123 & $92 \%$ \\
\hline LM9 & 5.10 & 30.7 & 1.7 & 2.184 & 0.26 & 0.032 & 0.043 & $<0.004$ & $<0.003$ & 39.5 & 0.39 & 0.052 & $14 \%$ \\
\hline LM12 & 7.02 & 19.9 & 0.040 & 0.002 & 0.17 & 0.013 & 0.102 & $<0.004$ & 0.068 & 33.9 & 0.26 & 0.199 & $76 \%$ \\
\hline LM13 & 7.12 & 16.7 & 0.633 & 0.107 & 0.123 & 0.021 & 0.103 & $<0.004$ & 0.036 & 34 & 0.04 & 0.028 & $67 \%$ \\
\hline LM14 & 7.92 & 25.5 & 0.029 & 0.049 & 0.164 & 0.023 & 0.137 & $<0.004$ & 0.127 & 25.8 & 0.60 & 0.574 & $96 \%$ \\
\hline LM15 & 7.17 & 37.3 & 2.16 & 1.233 & 0.365 & 0.019 & 0.070 & $<0.004$ & 0.015 & 39 & 1.31 & 0.463 & $35 \%$ \\
\hline LM16 & 7.48 & 28.2 & $<0.005$ & 0.002 & 0.22 & 0.009 & 0.037 & $<0.004$ & 0.012 & 39.0 & 0.15 & 0.103 & $70 \%$ \\
\hline LM17 & 7.60 & 32.8 & $<0.005$ & 0.001 & 0.206 & 0.010 & 0.068 & $<0.004$ & 0.031 & 35.3 & 0.12 & 0.114 & $94 \%$ \\
\hline LM18 & 8.18 & 5.18 & 0.080 & 0.016 & 0.067 & 0.013 & 0.453 & $<0.004$ & 0.097 & 27.3 & 2.95 & 2.739 & $93 \%$ \\
\hline LM19 & 7.17 & 41.8 & $<0.005$ & 0.001 & 0.29 & 0.006 & 0.031 & $<0.004$ & 0.081 & 48.3 & 0.10 & 0.091 & $94 \%$ \\
\hline LM20 & 7.23 & 27.8 & $<0.005$ & 0.024 & 0.289 & 0.097 & 0.043 & $<0.004$ & 0.013 & 38 & 0.17 & 0.138 & $82 \%$ \\
\hline LM21 & 7.11 & 13.3 & 0.061 & 0.001 & 0.139 & 0.074 & 0.036 & $<0.004$ & 0.034 & 45 & 0.88 & 0.776 & $88 \%$ \\
\hline LM22 & 7.27 & 30.7 & $<0.005$ & 0.003 & 0.27 & 0.017 & 0.033 & $<0.004$ & 0.011 & 44.5 & 0.29 & 0.266 & $91 \%$ \\
\hline LM23 & 6.50 & 35.3 & $<0.005$ & 0.043 & 0.36 & 0.11 & 0.040 & $<0.004$ & 0.023 & 51.2 & 0.30 & 0.254 & $84 \%$ \\
\hline
\end{tabular}

${ }^{*} \mathrm{PO}_{4}-\mathrm{P}$ was calculated from the concentration of $\mathrm{PO}_{4}{ }^{3-}$ as analyzed by ion chromatography

${ }^{* *}$ TDP is the concentration of $\mathrm{P}$ as analyzed by inductively coupled plasma-optical emission spectroscopy 
samples, particularly given that the latter may have a very low concentration of $\mathrm{Fe}$ (III)-(hydro)oxides. In addition, because the groundwater sampled from wells LM12, LM17, $L M 21, L M 22$, and LM23 have a relatively high concentration of $\mathrm{NO}_{3}{ }^{-}$(Fig. 11), it is also likely that anthropogenic sources may be considered as having a potential impact on the levels of dissolved $\mathrm{PO}_{4}{ }^{3-}$ measured therein.

\section{Conclusion}

The chemical composition of groundwater in and around Mataram City, Lombok Island, Indonesia was investigated to identify the species and potential sources of $P$ in groundwater. The concentration of TDP in the groundwater samples ranged from approximately 0.04 to $2.95 \mathrm{mg} \mathrm{l}^{-1}$, with $\mathrm{PO}_{4}{ }^{3-}$ representing the predominant ion therein. The potential source of dissolved $\mathrm{PO}_{4}{ }^{3-}$ in most of the groundwater samples is the dissolution of hydroxyapatite and/ or vivianite. However, the potential source of dissolved $\mathrm{PO}_{4}{ }^{3-}$ in groundwater with a TDP concentration of $\geq \mathrm{mg} \mathrm{I}^{-1}$ is more likely to be the reduction of $\mathrm{Fe}(\mathrm{III})$-(hydro)oxides, the decomposition of organic matter, or the dissolution of carbonate-rich fluorapatite. The geochemical approach used in this study was effective, even in the absence of detailed geological data, for the evaluation of the potential sources of $P$ in groundwater. The geochemical findings could aid researchers working on coastal marine ecosystems.

Funding This work was supported by JSPS KAKENHI (Grant-in-Aid for Scientific Research B) Grant Number 17H04494.

\section{Compliance with ethical standards}

Conflict of interest On behalf of all the authors, the corresponding author states that there are no conflicts of interest to declare.

Open Access This article is licensed under a Creative Commons Attribution 4.0 International License, which permits use, sharing, adaptation, distribution and reproduction in any medium or format, as long as you give appropriate credit to the original author(s) and the source, provide a link to the Creative Commons licence, and indicate if changes were made. The images or other third party material in this article are included in the article's Creative Commons licence, unless indicated otherwise in a credit line to the material. If material is not included in the article's Creative Commons licence and your intended use is not permitted by statutory regulation or exceeds the permitted use, you will need to obtain permission directly from the copyright holder. To view a copy of this licence, visit http://creativecommons .org/licenses/by/4.0/.

\section{References}

1. Adyasari D, Oehler T, Afiati N, Moosdorf N (2018) Groundwater nutrient inputs into an urbanized tropical estuary system in Indonesia. Sci Total Environ 627:1066-1079. https://doi. org/10.1016/j.scitotenv.2018.01.281

2. Oehler T, Eiche E, Putra D, Adyasari D, Hennig H, Mallast U, Moosdorf N (2018) Seasonal variability of land-ocean groundwater nutrient fluxes from a tropical karstic region (southern Java, Indonesia). J Hydrol 565:662-671. https://doi.org/10.1016/j. jhydrol.2018.08.077

3. Oehler T, Bakti H, Lubis RF, Purwoarminta A, Delinom R, Moosdorf $\mathrm{N}$ (2019) Nutrient dynamics in submarine groundwater discharge through a coral reef (western Lombok, Indonesia). Limnol Oceanogr 64:2646-2661. https://doi.org/10.1002/Ino.11240

4. Burke L, Selig L, Spalding M (2002) Reefs at risk in Southeast Asia. World Resources Institute. https://www.wri.org/publicatio n/reefs-risk-southeast-asia. Accessed 31 July 2020

5. Smith GD, Wetselaar R, Fox JJ, Hidayati D, Yogasawara H (2000) Ingestion of nitrate from well water by village people in Indonesia. AMBIO J Human EnviroN 29:525-527. https://doi. org/10.1579/0044-7447-29.8.525

6. Onodera S, Saito M, Sawano M, Hosono T, Taniguchi M, Shimada J, Umezawa Y, Lubis RF, Buapeng S, Delinom R (2008) Effects of intensive urbanization on the intrusion of shallow groundwater into deep groundwater: examples from Bangkok and Jakarta. Sci Total Environ 404:401-410. https://doi.org/10.1016/j.scito tenv.2008.08.003

7. Umezawa $U$, Hosono $T$, Onodera $S$, Siringan $F$, Buapeng $S$, Delinom R, Yoshimizu C, Tayasu I, Nagata T, Taniguchi M (2008) Source of nitrate and ammonium contamination in groundwater under developing Asian megacities. Sci Total Environ 404:361-376. https://doi.org/10.1016/j.scitotenv.2008.04.021

8. Delinom RM, Assegaf $A$, Abidin HZ, Taniguchi M, Suherman D, Lubis RF, Yulianto E (2009) The contribution of human activities to subsurface environment degradation in Greater Jakarta Area, Indonesia. Sci Total Environ 407:3129-3141. https://doi. org/10.1016/j.scitotenv.2008.10.003

9. Kagabu M, Shimda J, Delinom R, Tsuijimura $M$, Taniguchi $M$ (2011) Groundwater flow system under a rapidly urbanizing coastal city as determined by hydrogeochemistry. J Asian Earth Sci 40:226-239. https://doi.org/10.1016/j.jseaes.2010.07.012

10. Hosono T, Nakano T, Shimizu Y, Onodera S, Taniguchi M (2011) Hydrological constraint on nitrate and arsenic contamination in Asian metropolitan groundwater. Hydrol Processes 25:27422754. https://doi.org/10.1002/hyp.8015

11. Suryono CA (2015) The toxic metal arsenic contamination of the coastal aquifers in the north coast of Java Indonesia. Tropical Mar J 18:76-81. https://doi.org/10.14710/jkt.v18i2.518

12. Rusydi AF, Saito M, loka S, Maria R, Onodera S (2019) Estimation of ammonium sources in Indonesian coastal alluvial groundwater using $\mathrm{Cl}^{-}$and GIS. Int J Geomate. 17:53-58. https://doi. org/10.21660/2019.62.4749

13. Robertson WD, Cherry JA, Sudicky EA (1991) Groundwater contamination from two small septic systems on sand aquifers. Groundwater 29:82-92. https://doi. org/10.1111/j.1745-6584.1991.tb00500.x

14. Robertson WD, Schiff SL, Ptacek CJ (1998) Review of phosphate mobility and persistence in 10 septic system plumes. Groundwater 36:1000-1010. https://doi.org/10.1111/j.1745-6584.1998. tb02107.x

15. Robertson WD, Van Stempvoort DR, Schiff SL (2019) Review of phosphate attenuation in groundwater plumes from 24 septic systems. Sci Total Environ 692:640-652. https://doi. org/10.1016/j.scitotenv.2019.07.198 
16. Stuart ME, Lapworth DJ (2016) Macronutrient status of UK groundwater: nitrogen, phosphorus and organic carbon. Sci Total Environ 572:1543-1560. https://doi.org/10.1016/j.scito tenv.2016.02.181

17. Domagalski J, Johnson HM (2011) Subsurface transport of orthophosphate in five agricultural watersheds, USA. J Hydrol 409:157-171. https://doi.org/10.1016/j.jhydrol.2011.08.014

18. Puckett LJ, Zamora C, Essaid H, Wilson JT, Johnson HM, Brayton MJ, Vogel JR (2008) Transport and fate of nitrate at the groundwater/surface-water interface. J Environ Qual 37:1034-1050. https://doi.org/10.2134/jeq2006.0550

19. Lewandowski J, Meinikmann K, Nützmann G, Rosenberry DO (2015) Groundwater-the disregarded component in lake water and nutrient budgets. Part 2: effects of groundwater on nutrients. Hydrol Processes 29:2922-12955. https://doi.org/10.1002/ hyp. 10384

20. Winkel L, Berg M, Stengel C, Rosenberg T (2008) Hydrogeological survey assessing arsenic and other groundwater contaminants in the lowlands of Sumatra, Indonesia. Appl Geochem 23:30193028. https://doi.org/10.1016/j.apgeochem.2008.06.021

21. Neidhardt $\mathrm{H}$, Schoeckle D, Schleinitz A, Eiche E, Berner Z, Tram PTK, Lan VM, Viet PH, Biswas A, Majumder S, Chatterjee D, Oelmann Y, Berg M (2018) Biogeochemical phosphorus cycling in groundwater ecosystems-Insights from South and Southeast Asian floodplain and delta aquifer. Sci Total Environ 644:13571370. https://doi.org/10.1016/j.scitotenv.2018.07.056

22. Danish Energy Agency, Ea Energy Analyses (2019) Lombok energy outlook. https://www.ea-energianalyse.dk/en/publi cations/1858-the-lombok-energy-outlook-2030/. Accessed 31 July 2020

23. Widayanti BH, Hirsan FP, Kurniawan A (2017) Effectiveness of waste management in Mataram City. IOP Conf Ser Earth Environ Sci. 70:01204

24. Yasin S, Brotopuspito KS, Sartohadi J, Suryanto W, Adhi MA (2014) Local seismic hazard assessment of the Mataram City, Indonesia based in single station microtremor measurement. https://www.researchgate.net/publication/285299292_LOCAL _SEISMIC_HAZARD_ASSESSMENT_OF_THE_MATARAM_CITY_ INDONESIA BASED ON SINGLE STATION MICROTREMOR MEASUREMENT. Accessed 3 June 2020

25. Hiden $\mathrm{H}$, Brotopuspito KS, Hadmoko DS, Lavigne F, Airaksinen KB, Mutaqin BW, Hananto ND, Handayani L, Sudrajat Y, Suryanto W (2017) The isopach mapping of volcanic deposits of Mount Samalas 1257 AD based on the values of resistivity and physical properties. Geosciences 7:67. https://doi.org/10.3390/geosc iences7030067

26. Mangga SA, Atmawinata $S$, Hermanto B, Setyogroho B, Amin TC (1994) Geological map of the Lombok sheet, Nusatenggara
Barat Scale: 250,000. Geological Research and Development Center, Banding, Indonesia

27. Parkhurst DL, Appelo CAJ (2013) Description of input and examples for PHREEQC version 3: a computer program for speciation, batch-reaction, one-dimensional transport, and inverse geochemical calculations. In: U.S. geological survey techniques and methods, book 6, chap. A43, 497 p. https://pubs.usgs.gov/ $\mathrm{tm} / 06 / \mathrm{a} 43 /$

28. Worsfold P, McKelvie I, Monbet P (2016) Determination of phosphorus in natural waters: a historical review. Anal Chim Acta 918:8-20. https://doi.org/10.1016/j.aca.2016.02.047

29. Crompton TR (1996) Determination of anions: a guide for the analytical chemist. Springer-Verlag, Berlin Heidelberg, Berlin

30. Edmunds WM, Smedley P (2013) Fluoride in natural waters. In: Selinus O (ed) Essentials of Medical Geology. Springer, Dordrecht, pp 311-336

31. Schafer D, Donn M, Atteia O, Sun J, MacRae C, Raven M, Pejcic B, Prommer $\mathrm{H}$ (2018) Fluoride and phosphate release from carbonate-rich fluorapatite during managed aquifer recharge. J Hydrol 562:809-820. https://doi.org/10.1016/j.jhydrol.2018.05.043

32. Felitsyn SB (2002) The redistribution of phosphorus in basic volcanic rocks. Lithol Miner Resour 37:94-96. https://doi. org/10.1023/A:1013695708085

33. Nanzyo M, Ebuchi Y, Kanno H (2003) Apatite in the pyroclastic flow deposit (1990-1995) of the Unsen volcano, Japan, and its utilization by buckwheat. Phosphorus Res Bull 16:1-10. https:// doi.org/10.3363/prb1992.16.0_1

34. Foden JD (1983) The petrology of the calcalkaline lavas of Rindjani volcano, East Sunda: a model for Island Arc petrogenesis. J Petrol 24:98-130. https://doi.org/10.1093/petrology/24.1.98

35. Rachamat $H$, Rosana MF, Wirakusumah AD, Jabbar GA (2016) Petrogenesis of Rindjani Post-1257-Caldera-Forming-Eruption Lava Flows. Indones J on Geosci 3:107-126. https://doi. org/10.17014/ijog.3.2.107-126

36. Nyenje PM, Foppen JW, Kulabako R, Muwanga A, Uhlenbrook $S$ (2013) Nutrient pollution in shallow aquifers underlying pit latrines and domestic solid waste dumps in urban slums. J Environ Manage 122:15-24. https://doi.org/10.1016/j.jenvm an.2013.02.040

Publisher's Note Springer Nature remains neutral with regard to jurisdictional claims in published maps and institutional affiliations. 